\title{
Keefektifan Model Pembelajaran Think Pair and Share (TPS) Terhadap Nilai Belajar IPS
}

\author{
Novita Dewi Hastuti ${ }^{1}$, Sunan Baedowi ${ }^{2}$, Singgih Adhi Prasetya ${ }^{3}$ \\ ${ }^{123}$ Jurusan Pendidikan Guru Sekolah Dasar, Fakultas IImu Pendidikan \\ Universitas PGRI Semarang \\ Email: novitadewi2012@gamail.com ${ }^{1}$, sunanabin@yahoo.co.id ${ }^{2}$, \\ singgihadhiprasetyo@gmail.com ${ }^{3}$
}

\begin{abstract}
Abstrak
Penelitian ini bertujuan untuk mengetahui keefektifan model pembelajaran Think Pair and Share (TPS) terhadap nilai belajar IPS siswa kelas IV SD Negeri Kalimanggis. Penelitian ini merupakan penelitian eksperimen jenis kuantitatif. Penelitian ini menggunakan desain One Group Pretest-Posttest Design. Populasi dalam penelitian ini adalah seluruh siswa kelas IV SD Negeri Kalimanggis berjumlah 18 siswa tahun ajaran 2019/2020. Data dalam penelitian ini diperoleh melalui (1) tes (2) observasi (3) wawancara dan (4) dokumentasi. Analisis data dalam penelitian ini menggunakan uji normalitas, uji hipotesis (uji-t), dan uji ketuntasan belajar. Hasil penelitian yang dilakukan dapat disimpulkan bahwa model pembelajaran Think Pair and Share (TPS) efektif terhadap nilai belajar IPS siswa kelas IV SD Negeri Kalimanggis. Hal ini dapat dilihat dari rata-rata hasil posttest lebih tinggi daripada pretest selain itu diperkuat dengan hasil perhitungan uji $t$ diperoleh $t_{\text {hitung }}$ untuk nilai belajar sebesar 16,09968944 dan $t_{\text {tabel }} 2,0232$ karena $t_{\text {hitung }}(16,09968944)>t_{\text {tabel }}(2,0232)$ maka hal ini menunjukkan bahwa uji $t$ nilai belajar signifikan.
\end{abstract}

Kata-kata kunci: (TPS), Nilai Belajar Siswa, IPS.

\begin{abstract}
This study aims to determine the effectiveness of Think Pair and Share (TPS) learning models for the value of social studies learning for fourth grade students of SD Negeri Kalimanggis. This research is a quantitative type of experimental research. This study uses a one group pretest-posttest design. The population in this study were all grade IV students of SD Negeri Kalimanggis totalling 18 students in the 2019/2020 school year. The data in this study were obtained through (1) tests (2) observations (3) interviews (4) documentation. Data analysis in this study used the normality test, hypothesis test (t-test), and learning completeness test. The results of the study conducted can be concluded that the Think Pair and Share (TPS) learning model is effective against the social studies learning value of fourth grade students of $S D$ Negeri Kalimanggis. This can be seen from the average posttest result which are higher than the pretest but is reinforced by the results of the $t$ test calculation obtained tcount for learning value of 16,09968944 and t table 2,0232 because tcount $(16,09968944)>t$ table $(2,0232)$ then this shows that the $t$ test value significant learning.
\end{abstract}

Keywords: (TPS), Student Laerning Value, Social Studies.

\section{Pendahuluan}

Pendidikan merupakan suatu hal yang sangat penting guna mengembangkan potensi diri dari setiap individu. Menurut Undang-Undang Republik Indonesia Nomor 20 Tahun 2003 Bab I Pasal 1 tentang Sistem Pendidikan Nasional: Pendidikan adalah usaha sadar dan terencana untuk mewujudkan suasana belajar dan proses pembelajaran agar peserta didik secara aktif mengembangkan potensi dirinya untuk memiliki kekuatan spiritual keagamaan, pengendalian diri, kepribadian, kecerdasan, akhlak mulia, serta keterampilan yang diperlukan dirinya, masyarakat, bangsa dan negara.

Pendidikan dasar adalah pendidikan yang memberikan pengetahuan dan keterampilan, menumbuhka sikap dasar yang diperlukan dalam masyarakat, serta mempersiapkan siswa untuk mengikuti pendidikan menengah. Pendidikan di sekolah dasar sangat penting karena pendidikan di sekolah dasar dapat menjadi bekal dasar 
bagi siswa untuk hidup di dalam lingkungan masyarakat kelak. Bekal ilmu yang di dapat oleh siswa ketika melaksanakan pendidikan di sekolah dasar dapat menjadi bekal ilmu untuk mempersiapkan dalam melanjutkan pendidikan yang lebih tinggi serta menjadi warga masyarakat yang lebih baik. Untuk itu pendidikan di sekolah dasar sebagai wadah pendidikan yang mendasari dari lembaga pendidikan yang lebih tinggi atau pendidikan menengah seperti yang dijelaskan dalam Undang-Undang Sistem Pendidikan Nasional Nomor 20 Tahun 2003 Bab VI pasal 17 ayat 1 menyebutkan bahwa "Pendidikan dasar merupakan jenjang pendidikan yang melandasi jenjang pendidikan menengah".

Berdasarkan Peraturan Pemerintah Republik Indonesia Nomor 19 Tahun 2005 tentang Standar Nasional Pendidikan sebagaimana telah diubah dengan Peraturan Pemerintah Nomor 32 Tahun 2013 tentang Perubahan atas Peraturan Pemerintah Nomor 19 Tahun 2005 bahwa : Proses pembelajaran pada satuan pendidikan diselenggarakan secara interaktif, inspiratif, menyenagkan, menantang, memotivasi peserta didik untuk berpartisipasi aktif, serta memberikan ruang yang cukup bagi prakarsa, kreativitas, dan kemandirian sesuai dengan bakat, minat, dan perkembangan fisik serta psikologis peserta didik. Untuk itu setiap satuan pendidikan melakukan perencanaan pembelajaran, pelaksanaan proses pembelajaran serta penilaian proses pembelajaran untuk meningkatkan efisiensi dan efektivitas ketercapaian kompetensi lulusan.

Untuk meningkatkan efisiensi dan efektivitas ketercapaian kompetensi lulusan di sekolah dasar diperlukan perencanaan pembelajaran yang sesuai dengan tujuan pembelajaran yang akan dicapai, salah satu yang berperan penting dalam melaksanakan perencanaan pembelajaran tersebut yaitu guru. Menurut UndangUndang Nomor 14 Tahun 2005 Pasal 1 bahwa "Guru adalah pendidik profesional dengan tugas utama mendidik, mengajar, membimbing, mengarahkan, melatih, menilai, dan mengevaluasi peserta didik pada pendidikan anak usia dini jalur pendidikan formal, pendidikan dasar, dan pendidikan menengah".

Dalam melaksanakan pembelajaran guru harus memilih model pembelajaran yang tepat, yang sesuai dengan materi yang akan diajarkan kepada siswa, sehingga dengan adanya model pembelajaran yang tepat yang disesuaikan dengan materi yang akan diajarkan, diharapkan dapat mempermudah guru dalam menyampaikan materi serta mempermudah peserta didik dalam menerima materi. Pemilihan model pembelajaran secara tepat oleh guru merupakan langkah awal dalam menempuh suatu keberhasilan dalam pembelajaran yang pada akhirnya akan meningkatkan prestasi belajar siswa. Di sekolah dasar ada beberapa mata pelajaran yang wajib dikuasai oleh siswa salah satunya adalah ilmu pengetahuan sosial. IImu Pengetahuan Sosial (IPS) merupakan integrasi dari berbagai cabang ilmu-ilmu sosial dan humaniora, yaitu : sosiologi, sejarah, georafi, ekonomi, politik, hukum, dan budaya (Dalam Ahmad Susanto 2014:6). Pentingnya pembelajaran IPS di SD agar siswa memahami tentang ilmu sosial yang ada di lingkungan sekolah dan masyarakat. Serta mampu menjalankan, mematuhi norma-norma yang ada di lingkungan masyarakat agar menjadi siswa yang mampu mengamalkan nilai-nilai tersebut.

Menurut Astuti (2017:329) IImu Pengetahuan Sosial (IPS) adalah mata pelajaran yang mengkaji kehidupan sosial yang bahannya didasarkan pada bahan kajian sejarah, geografi, ekonomi, sosiologi, antropologi dan tata negara. IPS yang diajarkan di SD terdiri dari atas dua kajian pokok, pengetahuan sosial dan sejarah mata pelajaran yang memberikan bekal kepada siswa, agar siswa dapat menjadi makhluk sosial yang baik, sehingga dalam kehidupannya dapat diterima dengan baik pula oleh lingkungan masyarakatnya (Dinas Pendidikan Nasional, 2012:159 dalam Astuti, 2017:329). Selain itu pembelajaran IPS di SD juga mengajarkan siswa untuk saling tolong menolong, bekerja sama, dan saling gotong royong karena pada hakikatnya manusia tidak dapat hidup sendiri dan membutuhkan bantuan orang lain. Lewat pembelajaran IPS diharapkan siswa dapat mengenal berbagai jenis pekerjaan yang ada di lingkungan masyarakat dan mampu menyebutkan contoh jenis pekerjaan 
seperti guru, dokter, dan lain sebagainya. Dalam pembelajaran IPS siswa juga diharapkan dapat memiliki gambaran sebuah cita-cita yang akan ditempuh melalui pendidikan ke jenjang yang lebih tinggi. Sehingga pembelajaran IPS dapat membantu siswa memahami dan menentukan jenis pekerjaan di lingkungan masyarakat.

Menurut Donni Juni Priansa (2017:55) belajar merupakan proses perubahan dalam kepribadian manusia sebagai hasil dari pengalaman atau interaksi antara individu dan lingkungan. Perubahan tersebut ditampakkan dalam bentuk peningkatan kualitas dan kuantitas tingkah laku, seperti peningkatan kecakapan, pengetahuan, sikap, kebiasaan, pemahaman, keterampilan, daya pikir, dan kemampuan-kemampuan yang lain. Perubahan perilaku inilah yang menjadi tolak ukur keberhasilan proses belajar yang dialami oleh peserta didik. Belajar merupakan salah satu faktor yang memengaruhi dan berperan penting dalam pembentukan pribadi dan perilaku individu (Rusman, 2017:76).

Menurut Rusman (2017:84) dalam Wardani, dkk (2019) menyatakan bahwa pembelajaran merupakan proses interaksi antara guru dan siswa, baik interaksi secara langsung seperti kegiatan tatap muka maupun secara tidak langsung, yaitu dengan menggunakan berbagai media pembelajaran.

Menurut Dimyati dan Mudjiono (2009:3) hasil belajar merupakan hasil dari suatu interaksi tindak belajar dan tindak mengajar. Hasil belajar diperoleh dari pembelajaran dimana dalam pembelajaran terjadi hubungan timbal balik antara pelajar dan pengajar. Hubungan timbal balik tersebut dapat memperoleh suatu hasil belajar.

Hasil belajar adalah sejumlah pengalaman yang diperoleh siswa yang mencakup ranah kognitif, afektif, dan psikomotorik (Rusman, 2017:129). Ranah kognitif yaitu mencakup aspek pengetahuan, ranah afektif mencakup aspek sikap, dan ranah psikomotorik mencakup aspek keterampilan. Perumusan aspek-aspek kemampuan yang menggambarkan output peserta didik yang dihasilkan dari proses pembelajaran dapat digolongkan ke dalam tiga klasifikasi berdasarkan taksonomi Bloom (dalam Rusman 2017:131): 1) Domain kognitif; berkenaan dengan kemampuan dan kecakapan-kecakapan intelektual berpikir. 2) Domain afektif; berkenaan dengan sikap, kemampuan dan penguasaan segi-segi emosional, yaitu perasaan, sikap, dan nilai. 3) Domain psikomotor; berkenaan dengan suatu keterampilan-keterampilan atau gerkangerakan fisik.

Dalam menentukan kualitas hasil belajar siswa terdapat dua factor yang mempengaruhi yaitu faktor (intern) dan faktor (ekstern). Faktor dari dalam diri siswa meliputi kecerdasan, motivasi, minat, sikap, bakat, dan rasa percaya diri. Faktor dari luar diri siswa meliputi keluarga, sekolah dan masyarakat,. Kesuksesan guru dalam proses pembelajaran dapat memberikan dampak yang positif bagi siswa sehingga proses pembelajaran akan menjadi lebih aktif dan hasil belajar akan meningkat. Pembelajaran merupakan suatu proses yang membuat orang belajar. Setiap proses pembelajaran tersebut, peranan guru selaku pendidik bertugas membantu peserta didik agar dapat belajar dengan baik dan mudah. Disamping itu, siswa selaku peserta didik berusaha untuk mencari informasi, memecahkan masalah, dan mengemukakan pendapatnya. Inti dari proses pendidikan adalah proses pembelajaran yang terjadi di dalam kelas. Dengan demikian, perbaikan mutu pendidikan harus dimulai dengan menata dan meningkatkan mutu pembelajaran di kelas (Memorata: 2017 dalam Afiyahni, dkk: 2019).

Berdasarkan hasil observasi dan wawancara dengan wali kelas IV SD $N$ Kalimanggis, bapak Ahmad Zaenudin J.S diperoleh data bahwa proses pembelajaran yang dilaksanakan guru sudah menggunakan metode diskusi dan juga tanya jawab, guru juga sudah menggunakan model pembelajaran kooperatif salah satunya model pembelajaran yang bersifat diskusi. Namun, ketika pembelajaran berlangsung siswa masih kesulitan dan malas mengikuti proses pembelajaran, utamanya dalam memahami materi yang diajarkan. Hal tersebut menyebabkan nilai pada mata pelajaran IPS pada subtema jenis-jenis pekerjaan yang rendah pada siswa kelas IV yang masih dibawah kriteria ketuntasan minimal (KKM) yang ditetapkan sekolah yaitu 
75, dari 26 siswa hanya 10 siswa yang mampu mencapai kriteria ketuntasan minimal (KKM).

Untuk mengatasi permasalahan tersebut, dapat diterapkan model pembelajaran yang dapat menunjang proses pembelajaran. Model pembelajaran adalah suatu perencanaan atau suatu pola yang digunakan sebagai pedoman dalam merencanakan pembelajaran di kelas atau pembelajaran dalam tutorial (Trianto, 2010:51). Menurut Trianto (2010:52) model pembelajaran adalah kerangka konseptual yang melukiskan prosedur sistematik dalam mengorganisasikan pengalaman belajar untuk mencapai tujuan belajar tertentu dan berfungsi sebagai pedoman bagi perancang pembelajaran dan para guru dalam merancang dan melaksanakan pembelajaran. Dengan demikian model pembelajaran sangat penting bagi pengajar karena dengan adanya model pembelajaran dapat mempermudah pengajar dalam melaksanakan proses pembelajaran sehingga tujuan pembelajaran di dalam kelas dapat tercapai dan akan sesuai dengan apa yang diharapkan oleh pengajar.

Model pembelajaran yang dapat diterapkan yaitu model pembelajaran Think Pair and Share (TPS). Model pembelajaran Think Pair and Share (TPS) merupakan jenis pembelajaran kooperatif yang dirancang dalam bentuk diskusi yang dapat meningkatkan kemampuan berpikir, keterampilan berkomunikasi siswa dan mendorong partisipasi mereka dalam kelas (Azlina, 2010:23-24 dalam Nurnawati, Yulianti, dan Susanto, 2012). Model pembelajaran Think Pair and Share (TPS) memungkinkan siswa aktif didalam kelas karena guru akan memberikan suatu masalah atau pertanyaan kepada siswa kemudian siswa berpikir sendiri mengenai jawaban atas permasalahan yang diberikan oleh guru. Strategi ini memperkenalkan gagasan tentang waktu 'tunggu atau berpikir' (wait or think time) pada elemen interaksi pembelajaran kooperatif yang saat ini menjadi salah satu faktor ampuh dalam meningkatkan respons siswa terhadap pertanyaan (Miftahul Huda, 2013:206).

Siswa juga diberikan kesempatan untuk berdiskusi dengan teman melalui kelompok berpasangan lalu dari hasil diskusi berpasangan, siswa dapat mengkomunikasikan hasil diskusi di depan kelas sehingga seluruh siswa menjadi paham dan bersama dengan guru dapat menyimpulkan hasil diskusi. Menurut Miftahul Huda (2013:206) manfaat TPS antara lain adalah: 1) Memungkinkan siswa untuk bekerja sendiri dan bekerja sama dengan orang lain. 2) Mengoptimalkan partisipasi siswa. 3) Memberi kesempatan kepada siswa untuk menunjukkan partisipasi mereka kepada orang lain.

Melalui kegiatan tersebut diharapkan siswa dapat berpikir aktif, meningkatkan keterampilan bekerja sama, dan melatih siswa dalam keterampilan berkomunikasi. Sehingga hasil dari pembelajaran dapat bermakna dan juga dapat meningkatkan nilai belajar siswa. Menurut Jumanta Hamdayama (2014:203) kelebihan model pembelajaran Think Pair Share sebagai berikut: 1) Meningkatkan pencurahan waktu pada tugas. Penggunaan model pembelajaran Think Pair Share menuntut siswa menggunakan waktunya untuk mengerjakan tugas-tugas atau permasalahan yang diberikan oleh guru di awal pertemuan sehingga diharapkan siswa mampu memahami materi dengan baik sebelum guru menyampaikannya pada pertemuan selanjutnya. 2) Memperbaiki kehadiran. Tugas yang diberikan oleh guru pada setiap pertemuan selain untuk melibatkan siswa secara aktif dalam proses pembelajaran juga dimaksudkan agar siswa dapat selalu berusaha hadir pada setiap pertemuan. Sebab bagi siswa yang sekali tidak hadir maka siswa tersebut tidak mengerjakan tugas dan hal ini akan memengaruhi hasil belajar mereka. 3) Angka putus sekolah berkurang. Model pembelajaran Think Pair Share diharapkan dapat memotivasi siswa dalam pembelajaran sehingga hasil belajar siswa dapat lebih baik daripada pembelajaran dengan model konvensional. 4) Sikap apatis berkurang. Sebelum pembelajaran dimulai, kecenderungan siswa merasa malas karena proses belajar di kelas hanya mendengarkan apa yang disampaikan guru dan menjawab semua yang ditanyakan oleh guru. Dengan melibatkan siswa secara aktif dalam proses belajar mengajar, model pembelajaran Think Pair Share akan lebih menarik dan tidak monoton 
dibandingkan model konvensional. 5) Penerimaan terhadap individu lebih besar. Dalam model pembelajaran konvensional, siswa yang aktif di dalam kelas hanyalah siswa tertentu yang benar-benar rajin dan cepat dalam menerima materi yang disampaikan oleh guru sedangkan siswa lain hanyalah "pendengar" materi yang disampaikan oleh guru. Dengan pembelajaran Think Pair Share, hal ini dapat diminimalisir sebab semua siswa akan terlibat dengan permasalahan yang diberikan oleh guru. 6) Hasil belajar lebih mendalam. Parameter dalam proses belajar mengajar adalah hasil belajar yang diraih oleh siswa. Dengan pembelajaran Think Pair Share, perkembangan hasil belajar siswa dapat diidentifikasi secara bertahap, sehingga pada akhir pembelajaran, hasil yang diperoleh siswa dapat lebih optimal. 7) Meningkatkan kebaikan budi, kepekaan dan toleransi. Sistem kerja sama yang diterapkan dalam model pembelajaran Think Piar Share menuntut siswa untuk dapat bekerja sama dalam tim, sehingga siswa dituntut untuk dapat belajar berempati, menerima pendapat orang lain atau mengakui secara sportif jika pendapatnya tidak diterima.

Think Pair and Share (TPS) merupakan teknik pembelajaran dalam pembelajaran kooperatif yang pertama kali dikembangkan oleh Frank Lyman pada tahun 1981. TPS merupakan jenis pembelajaran kooperatif yang dirancang untuk mempengaruhi pola interaksi siswa. Teknik ini menghendaki siswa untuk bekerja sendiri dan bekerja sama saling membantu dengan siswa lain dalam suatu kelompok kecil. Dengan metode klasikal yang memungkinkan hanya satu siswa yang maju dan membagikan hasilnya untuk seluruh kelas, teknik Think Pair and Share memberi sedikitnya delapan kali kesempatan lebih banyak kepada setiap siswa untuk dikenali dan menunjukkan partisipasi mereka kepada orang lain (Anita Lie, 2008:57) dalam Kusuma dan Aisyah (2012).

Berdasarkan permasalahan diatas maka perlu dilakukan perbaikan pembelajaran agar kreativitas belajar siswa meningkat. Salah satunya dengan menggunakan model pembelajaran Think Pair and Share (TPS) pada pembelajaran IPS kelas IV.

Tujuan dari penelitian ini adalah untuk mengetahui keefektifan model pembelajaran Think Pair and Share (TPS) terhadap nilai belajar IPS siswa kelas IV.

\section{Metode}

Metode penelitian yang digunakan adalah penelitian eksperimen jenis kuantitatif yaitu dengan cara memberikan perlakuan kegiatan dalam pembelajaran di kelas. Peneliti menggunakan desain penelitian pre eksperimental design dengan jenis one group pre test and post tes design.

Penelitian ini dilaksanakan di SD Negeri Kalimanggis, Kecamatan Subah, Kabupaten Batang pada tanggal 9 - 11 Desember 2019 pada tahun ajaran 2019/2020 semester ganjil pada siswa kelas IV SD Negeri Kalimanggis.

Populasi dalam penelitian ini adalah seluruh siswa kelas IV SD Negeri Kalimanggis yang berjumlah 18 siswa tahun ajaran 2019/2020. Dalam desain ini subjek dikenakan perlakuan dua kali pengukuran, penilaian pertama dilakukan sebelum kegiatan dengan model pembelajaran Think Pair and Share (pre test) dan pengukuran ke dua dilakukan setelah kegiatan dengan model pembelajaran Think Pair and Share (post test). Dengan demikian hasil perlakuan dapat diketahui lebih akurat, karena dapat membandingkan dengan keadaan sebelum diberi perlakuan. Desain ini dapat digambarkan sebagai berikut:

\section{$\mathbf{O}_{1} \times \mathbf{O}_{2}$}

Gambar 01. One Group Pretest-Posttest

(Sugiyono,2014:111) 
Keterangan:

$\mathrm{O}_{1}=$ nilai pretest (sebelum diberi perlakuan)

$\mathrm{x}=$ perlakuan model pembelajaran Think Pair and Share

$\mathrm{O}_{2}=$ nilai posttest (setelah diberi perlakuan)

Teknik pengumpulan data dalam penelitian ini adalah tes, observasi, wawancara, dan dokumentasi. Tes bertujuan untuk mengukur pengetahuan siswa setelah mengikuti pembelajaran yang diberikan oleh guru. Observasi dilakukan peneliti dengan mengamati data-data hasil belajar siswa saat pembelajaran. Wawancara dilakukan peneliti untuk memperoleh data yang ada di sekolah melalui wawancara dengan guru kelas IV SD N Kalimanggis. Dokumentasi di peroleh dari dokumen yang ada di SD N Kalimanggis yaitu berupa data nama siswa yang menjadi sampel penelitian dan foto saat pembelajaran berlangsung.

Data nilai belajar siswa diambil dari hasil pretest dan posttest. Pretest untuk memperoleh data nilai belajar siswa sebelum diberikan pembelajaran dengan menggunakan model pembelajaran Think Pair and Share dan posttest untuk memperoleh data nilai belajar siswa setelah diberikan pembelajaran yaitu dengan menggunakan model pembelajaran Think Pair and Share.

Peserta didik dikatakan berhasil mencapai nilai belajar jika nilainya diatas KKM, yaitu $\geq 75$. Pengembangan instrumen tes terdiri dari beberapa tahapan, yaitu: (1) mengkaji silabus mata pelajaran IPS kelas IV SD; (2) menyusun kisi-kisi tes didasarkan pada teori yang dikembangkan oleh Bloom; (3) menulis butir soal; (4) menelaah butir soal; (5) melakukan uji coba; (6) menganalisis butir soal.

Setelah proses validasi berdasarkan pendapat ahli dilakukan, instrumen di ujicobakan pada siswa kelas V di SD Negeri Kalimanggis yang memiliki karakteristik yang hampir sama dengan siswa yang menjadi subjek penelitian ini.

Teknik analisis data peneliti menggunakan uji normalitas, uji hipotesis (uji-t), dan uji ketuntasan belajar. Uji normalitas untuk mengetahui kelas tersebut berdistribusi normal atau tidak. Uji hipotesis menggunakan uji t-test. Uji ketuntasan belajar digunakan untuk mengetahui tuntas atau tidaknya nilai belajar dengan tolak ukur KKM.

\section{Hasil dan Pembahasan}

Pada penelitian ini subyek dikenakan dua kali pengukuran, yang pertama sebelum kegiatan dengan menggunakan model pembelajaran Think Pair and Share, siswa diberikan soal pretest, dan yang kedua setelah kegiatan dengan menggunakan model pembelajaran Think Pair and Share, siswa diberikan soal posttest. Peneliti mengambil satu kelas sebagai sampel penelitian. Pengambilan sampel ini didasarkan pada kelas yang berdistribusi normal.

Data hasil uji coba normalitas awal menggunakan uji liliefors untuk nilai hasil pretest yang hasilnya didapatkan bahwa $L_{0}$ nilai belajar $(0,159288889)<L_{\text {tabel }}(0,2)$ maka $H_{0}$ diterima, sehingga sampel berasal dari populasi berdistribusi normal. Dari data uji normalitas menggunakan uji liliefors untuk hasil posttest memenuhi kriteria pengujian yaitu $L_{0}$ $(0,138755556)<L_{\text {tabel }}(0,2)$, hal ini menunjukkan bahwa sampel hasil posttest berdistribusi normal. Untuk mengetahui apakah model pembelajaran Think Pair and Share efektif terhadap nilai belajar IPS siswa kelas IV SDN Kalimanggis ini dilakukan analisis tahap akhir berupa uji t. Hasil analisis data akhir untuk pengujian hipotesis pada nilai belajar pretest dan posttest didapatkan $t_{\text {hitung }}(16,09968944)>t_{\text {tabel }}(2,0232)$ untuk nilai belajar, dimana menunjukkan bahwa $\mathrm{t}_{\text {hitung }}$ berada pada daerah penerimaan $\mathrm{H}_{\mathrm{a}}$. Hal ini menunjukkan bahwa model pembelajaran Think Pair and Share efektif terhadap nilai belajar IPS siswa kelas IV SD Negeri Kalimanggis. 
Tabel 01 Daftar Presentase Ketuntasan Nilai Belajar Siswa

\begin{tabular}{lcc}
\hline Keterangan & \multicolumn{2}{c}{ Nilai belajar } \\
\cline { 2 - 4 } & Pretest & Posttest \\
\hline Jumlah siswa & 18 & 18 \\
Siswa tuntas & 1 & 3 \\
Siswa tidak tuntas & 17 & 82,5 \\
Rata-rata & 43,05555556 & \\
Presentase Kenaikan & $39,4 \%$ & \\
\hline
\end{tabular}

(Sumber: Analisis Hasil Penelitian)

Dari tabel 1 didapatkan rata-rata nilai tes sebelum diberi perlakuan dengan model pembelajaran Think Pair and Share sebesar 43,05555556 dengan 17 siswa yang dinyatakan tidak tuntas dan 1 siswa yang dinyatakan tuntas. Setelah diberi pembelajaran dengan model pembelajaran Think Pair and Share nilai rata-rata posttest siswa adalah 82,5 dengan 3 siswa dinyatakan tidak tuntas, sedangkan 15 siswa dinyatakan tuntas. Presentase kenaikan sebesar $39,4 \%$. Sehingga dapat disimpulkan bahwa kemampuan awal siswa diperoleh rata-rata yang relatif masih rendah, namun setelah diberikan perlakuan dengan menggunakan model pembelajaran Think Pair and Share terdapat peningkatan nilai belajar IPS siswa.

Dari hasil penelitian diperoleh bahwa reaksi siswa dengan pembelajaran menerapkan model pembelajaran Think Pair and Share (TPS) yaitu dari siswa yang sebelumnya merasa malas dan tidak percaya diri ketika proses pembelajaran berlangsung menjadi siswa yang aktif serta bersikap antusias untuk belajar. Perubahan tingkah laku tersebut menunjukkan adanya respon positif yang diterima oleh siswa. Hal ini sejalan dengan pendapat Surya (1997) dalam Rusman (2017:76) belajar dapat diartikan sebagai suatu proses yang dilakukan oleh individu untuk memperoleh perubahan perilaku baru secara keseluruhan, sebagai hasil dari pengalaman individu itu sendiri dalam berinteraksi dengan lingkungannya.

Ketika proses pembelajaran dengan menggunakan model pembelajaran Think Pair Share (TPS) dapat membangun interaksi antar siswa karena proses pembelajaran pada tahap pair (berpasangan) siswa dituntut untuk bekerja sama dalam kelompok untuk membentuk sikap kepedulian antar sesama sehingga terbentuk suatu interaksi antara siswa dengan siswa yang lain dan juga antara siswa dengan guru. Sejalan dengan pendapat Jumanta Hamdayana (2014:201) bahwa model pembelajaran Think Pair Share (TPS) atau berpikir berpasangan berbagi merupakan jenis pembelajaran kooperatif yang dirancang untuk memengaruhi pola interaksi siswa.

Setelah menerapkan pembelajaran dengan menggunakan model pembelajaran Think Pair and Share (TPS) nilai belajar IPS siswa pada ranah kognitif naik. Hal ini dibuktikan dengan nilai rata-rata pretest siswa yaitu 43,0555555 kemudian setelah menerapkan model pembelajaran Think Pair and Share (TPS) berbantu animasi diperoleh nilai rata-rata posttest siswa menjadi 82,5.

Hasil belajar yang selanjutnya yaitu ranah psikomotorik. Dalam penelitian ini siswa dapat mengerjakan lembar diskusi yang telah guru bagikan untuk dikerjakan secara berkelompok berpasangan. Siswa aktif mengerjakan lembar diskusi dan juga siswa berani mempresentasikan hasil diskusinya didepan kelas. Lembar diskusi yang siswa kerjakan secara berkelompok berpasangan menghasilkan nilai yang mencapai kriteria sangat baik. Hal ini dibuktikan dengan hasil rata-rata nilai ranah psikomotorik siswa pada pertemuan pertama dan kedua mencapai 97,7916666667. Dalam hal ini ketika menerapkan model pembelajaran TPS siswa dapat memperoleh suatu pengetahuan yang baru melalui proses pembelajaran berdiskusi secara berpasangan sehingga memudahkan siswa untuk menemukan suatu konsep pengetahuan yang baru. Sejalan dengan pendapat Jumanta Hamdayana (2014:201) bahwa model pembelajaran TPS guru tidak lagi sebagai satu-satunya sumber pembelajaran (teccher oriented), tetapi justru siswa dituntut untuk dapat menemukan dan memahami konsepkonsep baru (student oriented).

Pada aspek psikomotor, peneliti menggunakan Lembar Kerja Peserta Didik (LKPD) dimana siswa mengerjakan LKPD melalui diskusi berpasangan, data yang diambil dan 
dianalisis untuk dibuktikan bahwa model pembelajaran Think Pair and Share lebih efektif terhadap nilai belajar IPS siswa materi jenis-jenis pekerjaan siswa kelas IV SD N Kalimanggis. Selama pembelajaran berlangsung yaitu pada pertemuan pertama dan ke dua siswa diminta mengerjakan LKPD tentang jenis-jenis pekerjaan. Pada pertemuan pertama siswa mengerjakan LKPD berupa diagram ven megenai jenis-jenis pekerjaan yang ada dilingkungan sekitar. Sebelumnya siswa dijelaskan terlebih dahulu materi tentang jenis-jenis pekerjaan dengan menggunakan model pembelajaran Think Pair and Share. Sedangkan pada pertemuan ke dua siswa mengerjakan LKPD berupa mengisi tabel dimana siswa diminta menyebutkan berbagai kegiatan ekonomi dan jenis pekerjaan yang berkaitan didalamnya. Pada pertemuan kedua ini siswa belajar tentang kegiatan ekonomi dengan menggunakan model pembelajaran Think Pair and Share. Penilaian aspek psikomotor ini dinilai dengan menggunakan rubrik penilaian.

Tabel 02. Daftar Nilai Aspek Psikomotor

\begin{tabular}{lrr}
\hline \multicolumn{1}{c}{ Keterangan } & Pertemuan ke- \\
\cline { 2 - 3 } & $\mathbf{1}$ & $\mathbf{2}$ \\
\hline Jumlah siswa & & 18 \\
18 & & 100 \\
Nilai tertinggi & & 93,75 \\
Nilai terendah & & 99,3055555556 \\
83,3 & & \\
Rata-rata & & \\
96,277777778 & & \\
\hline
\end{tabular}

Kelebihan menggunakan model pembelajaran Think Pair and Share (TPS) dalam pembelajaran dikelas yaitu dapat membangun interaksi antar siswa melalui diskusi berpasangan (tahap pair) sehingga terbentuk pengetahuan yang lebih mendalam. Selain itu siswa dapat berpikir secara mandiri dimana siswa dapat membangun pengetahuan yang dimilikinya sendiri dan ketika diskusi berlangsung siswa memperoleh pengetahuan baru dengan bertukar pikiran atau jawaban bersama dengan teman sebangkunya/pasangannya dalam kelompok. Dengan menerapkan model pembelajaran Think Pair and Share juga dapat meningkatkan rasa percaya diri dan tanggungjawab siswa sebab ketika proses pembelajaran siswa aktif bertanya dan menjawab pertanyaan yang disampaikan oleh guru dalam diskusi berpasangan. Sejalan dengan pendapat Alifatun (2014) bahwa model pembelajaran TPS menjadikan siswa lebih antusias dalam mengikuti pembelajaran dan berdiskusi, siswa merasakan iklim belajar yang lebih menyenangkan sehingga interaksi antara siswa dengan guru maupun antarsiswa menjadi meningkat.

Hasil nilai belajar yang maksimal dapat diperoleh jika proses pembelajaran yang dilaksanakan sesuai dengan sintak model pembelajaran Think Pair and Share (TPS) yang telah ada. Menurut Huda dalam Didimus (2014) langkah-langkah model pembelajaran TPS mengikuti langkah-langkah 1) siswa ditempatkan dalam kelompokkelompok (setiap kelompok terdiri atas empat anggota/siswa), 2) guru memberikan tugas kepada setiap kelompok, 3) masing-masing anggota memikirkan dan mengerjakan tugas tersebut sendiri-sendiri terlebih dahulu, 4) kelompok membentuk anggota-anggotanya secara berpasangan, 5) kedua pasangan lalu bertemu kembali dalam kelompok masing-masing untuk men-share hasil diskusinya.

Pada pelaksanaan proses penelitian ini terdapat beberapa kekurangan diantaranya adalah masih ada siswa yang mengobrol sendiri ketika proses pembelajaran berlangsung. Kemudian ada juga siswa yang menolak untuk dipasangkan dengan teman satu kelompoknya. Selain itu, model pembelajaran Think Pair and Share juga membutuhkan waktu yang cukup lama dan masih ada siswa yang pasif ketika proses pembelajaran.

Terlepas dari kekurangan yang ada pada penelitian ini, nilai belajar IPS siswa materi jenis-jenis pekerjaan juga mengalami peningkatan sebesar 39,4\%. Aktivitas siswa mengalami peningkatan sehingga berdampak pada nilai belajar siswa yang 
memuaskan. Setelah dilakukan perhitungan uji hipotesis yang telah dipaparkan pada analisis data akhir dan analisis pada penilaian aspek psikomotor yang telah dikerjakan oleh siswa maka diperoleh kesimpulan sebagai hasil dari nilai belajar IPS siswa kelas IV SD Negeri Kalimanggis. Penerapan model pembelajaran Think Pair and Share telah terbukti meningkatkan nilai belajar IPS siswa. Hasil penelitian ini sejalan dengan beberapa hasil penelitian sebelumnya yaitu sebagai berikut. Penelitian oleh Husna, dkk (2013) menyimpulkan bahwa peningkatan kemampuan pemecahan masalah matematis siswa dengan menggunakan model pembelajaran kooperatif Think Pair Share lebih baik daripada siswa yang memperoleh pembelajaran konvensional jika dilihat secara keseluruhan siswa, akan tetapi secara kategori peringkat siswa hanya pada peringkat siswa tinggi saja peningkatan kemampuan pemecahan masalah matematis siswa dengan menggunakan pembelajaran kooperatif Think Pair Share lebih baik daripada siswa yang memperoleh pembelajaran konvensional. Selanjutnya Surraya, dkk (2014) juga sependapat bahwa model pembelajaran TPS yang diterapkan dapat meningkatkan hasil belajar baik pada siswa yang memiliki keterampilan berpikir kritis tinggi maupun rendah, dan pada siswa yang memiliki keterampilan berpikir kritis rendah, hasil belajar justru meningkat signifikan pada model pembelajaran yang diterapkan. Hal tersebut sesuai dengan pembelajaran dengan menerapkan model pembelajaran Think Pair and Share (TPS), yaitu dalam pembelajaran siswa dapat membangun pengetahuannya sendiri kemudian berani mengungkapkan pendapatnya melalui diskusi berpasangan.

\section{Simpulan dan Saran}

Berdasarkan hasil penelitian yang telah dilakukan dapat disimpulkan bahwa model pembelajaran Think Pair and Share efektif terhadap nilai belajar IPS siswa kelas IV SD Negeri Kalimanggis. Di lihat dari rata-rata nilai posttest lebih tinggi daripada pretest selain itu, diperkuat dengan hasil perhitungan uji $t$ diperoleh $t_{\text {hitung }}$ sebesar 16,09968944 dan $t_{\text {tabel }}$ sebesar 2,0232 karena $t_{\text {hitung }}(16,09968944)<t_{\text {tabel }}(2,0232)$ maka hal ini menunjukkan bahwa uji t nilai belajar signifikan. Selain itu pada aspek psikomotor siswa juga memperoleh rata-rata nilai belajar IPS yang relatif bagus. Pada pertemuan ke-1 siswa memperoleh rata-rata sebesar 99,3055555556 dan pada pertemuan ke-2 siswa memperoleh rata-rata sebesar 96,27777777778.

Berdasarakan penelitian ini, maka saran yang dapat diajukan adalah sebagai berikut. 1) Dalam proses pembelajaran sebaiknya guru menggunakan model pembelajaran Think Pair and Share (TPS) karena berdasarkan hasil penelitian ini menunjukkan bahwa nilai belajar IPS siswa dengan pembelajaran yang menggunakan model pembelajaran Think Pair and Share (TPS) memperoleh nilai yang tinggi dan mengalami kenaikan nilai. 2) Hendaknya guru lebih meningkatkan motivasi yang dimiliki siswa dengan berbagai cara misalnya memberikan nilai tambah terhadap siswa yang aktif seperti bertanya dan memberikan tanggapan dalam mengikuti proses pembelajaran, sehingga siswa lebih bersemangat dalam mengikuti pembelajaran.

\section{Daftar Pustaka}

Afiyahni, Faizah Dwi., dkk. 2019. Keefektifan Model Pembelajaran Kooperatif Think Pair and Share Berbantu Media Diorama Terhadap Hasil Belajar Tematik Integratif. Mimbar PGSD Undiksha. 7(3): 230-236.

Astuti, D. 2017. Model Pembelajaran Think Pair Share (TPS) Untuk Meningkatkan Prestasi Belajar Mata Pelajaran IPS Kelas I. Jurnal Riset dan Konseptual. 2(3): 328-334.

Boleng, Tanah Didimus. 2014. Pengaruh Model Pembelajaran Cooperative Script dan ThinkPair-Share Terhadap Katerampilan Berpikir Kritis, Sikap Sosial dan Hasil Belajar Kognitif Biologi Siswa SMA Multietnis. Jurnal Pendidikan Sains. 2(2): 76-84.

Hamdayama, J. 2014. Model dan Metode Pembelajaran Kreatif \& Berkarakter. Bogor: Ghalia Indonesia.

Huda, M. 2013. Model-model Pengajaran dan Pembelajaran. Yogyakarta: Pustaka Pelajar.

Husna., dkk. 2013. Peningkatan Kemampuan Pemecahan Masalah dan Komunikasi Matematis Siswa Sekolah Menengah Pertama Melalui Model Pembelajaran Kooperatif Tipe ThinkPair Share (TPS). Jurnal Peluang. 1(2): 81-92. 
Kusuma, Febrian W., Aisyah, M. 2012. Implementasi Model Pembelajaran Kooperatif Tipe Think Pair Share Untuk Meningkatkan Aktivitas Belajar Akutansi Siswa Kelas IX IPS 1 SMA Negeri 2 Wonosari Tahun Ajaran 2011/2012. Jurnal Pendidikan Akutansi Indonesia. 10(2): 43-63.

Mufidah, L., dkk. 2013. Penerapan Model Pembelajaran Kooperatif Tipe TPS Untuk Meningkatkan Aktivitas Belajar Siswa Pada Pokok Bahasan Matriks. Jurnal Pendidikan Matematika STKIP PGRI Sidoarjo. 1(1): 117-125.

Ni'mah, Alfiatun. 2014. Penerapan Model Pembelajaran Think Pair Share (TPS) dengan Metode Eksperimen Untuk Meningkatkan Hasil Belajar dan Aktivitas Belajar Siswa Kelas VIII MTs Mahdlatul Muslimin Kudus. Skripsi. Universitas Negeri Semarang.

Nurnawati, E., Dwi, Y., dan Hadi, S. 2012. Peningkatan Kerjasama Siswa SMP melalui Penerapan Pembelajaran Kooperatif Pendekatan Think Pair Share. Unnes Physics Education Journal. 1(1): 1-7.

Peraturan Pemerintah, 2013. Undang-undang Nomor 20 tentang Sistem Pendidikan Nasional. Jakarta: Sekertariat Negara.

Peraturan Pemerintah. 2005. Undang-undang Nomor 19 tentang Standar Nasional Pendidikan. Jakarta: Sekertaiat Negara.

Peraturan Pemerintah. 2005. Undang-undang Nomor 14 tantang Guru dan Dosen. Jakarta: Sekertariat Negara.

Priansa, D, J. 2017. Pengembangan Strategi \& Model Pembelajaran. Bandung: CV Pustaka Setia.

Rusman. 2017. Belajar dan Pembelajaran Berorientasi Standar Proses Pendidikan. Jakarta: Kencana.

Sugiyono. 2014. Metode Penelitian Pendidikan. Bandung: Alfabeta.

Surraya, L., dkk. 2014. Pengaruh Model Pembelajaran Think Pair Share Terhadap Hasil Belajar IPA Ditinjau Dari Keterampilan Berpikir Kritis Siswa. e-Journal Program Pascasarjana Universitas Pendidikan Ganesha. 4: 1-11.

Susanto, A. 2014. Pengembangan Pembelajaran IPS di Sekolah Dasar. Jakarta: Prenadamedia Group.

Trianto. 2010. Model Pembelajaran Terpadu. Jakarta: PT Bumi Aksara.

Wardani, Decyta Khasuma., dkk. 2019. Pengaruh Model Pembelajaran Project Based Learning Terhadap Hasil Belajar Matematika. Mimbar PGSD Undiksha. 7(3): 207-213. 